\title{
Hubungan tingkat kepercayaan diri dengan obesitas pada siswa-siswi SMA Negeri 7 Manado
}

\author{
${ }^{1}$ Firman Wahyuni \\ ${ }^{2}$ Hendri Opod \\ ${ }^{2}$ Lydia David
}

\author{
${ }^{1}$ Kandidat Skripsi Fakultas Kedokteran Universitas Sam Ratulangi Manado \\ ${ }^{2}$ Bagian Psikologi Fakultas Kedokteran Universitas Sam Ratulangi Manado \\ Email: Firman.pak2e@gmail.com
}

\begin{abstract}
Self-confidence is a certain degree of suggestion that develops in a person, so that, he/she feels confident in doing something, and accepts oneself as what it is. One of the factors that can lowers a person's self confidence is the physical appearance. Thus, the tendency to be overweight or obese can be annoying and be a source of concern and lack of confidence over the years of adolescence; therefore, the teens will be vulnerable to a variety of psychological problems. This study aimed to obtain the relationship between level of confidence and obese students at SMA Negeri 7 Manado. This was a correlation study with a cross sectional design. Samples were 62 students obtained by using purposive sampling. The instrument of this study was the scale of confidence with reliability $(\alpha)=0.736$ based on the characteristics of selfconfidence which consisted of believe in oneself, act independently in making decisions, and have a positive sense of self. The results showed that confidence levels in obese adolescents were as follows: high category in 45 students (73\%), moderate category in 17 students (27\%); no low category was found. The Pearson correlation test showed an $r$ value $=-0.083$ and a $p$ value $=0.519$. Conclusion: There was a negative relationship between self-confidence and obesity, albeit, the level of correlation was weak and insignificant.
\end{abstract}

Keywords: obesity, self confidence

\begin{abstract}
Abstrak: Kepercayaan diri adalah suatu tingkatan rasa sugesti tertentu yang berkembang dalam diri seseorang sehingga merasa yakin dalam berbuat sesuatu, dan menerima diri apa adanya. Salah satu faktor yang dapat menurunkan kepercayaan diri seseorang ialah masalah penampilan fisik. Adanya kecenderungan menjadi gemuk atau mengalami obesitas dapat mengganggu dan menjadi sumber keprihatinan dan kurangnya rasa percaya diri selama bertahun-tahun masa remaja sehingga remaja akan rentan terhadap berbagai masalah psikologik. Penelitian ini bertujuan untuk melihat hubungan tingkat kepercayaan diri pada siswa yang mengalami obesitas di SMA Negeri 7 Manado. Jenis penelitian ini korelasional dengan rancangan potong lintang. Jumlah responden sebanyak 62 orang diperoleh dengan teknik purposive sampling. Alat ukur yang dipakai ialah skala kepercayaan diri dengan reliabilitas $(\alpha)=0,736$ berdasarkan ciri kepercayaan diri yaitu: percaya pada kemampuan diri sendiri, bertindak mandiri dalam mengambil keputusan, dan memiliki rasa positif terhadap diri sendiri. Hasil penelitian menunjukkan tingkat kepercayaan diri pada remaja yang obes berada pada kategori tinggi sebanyak 45 orang (73\%), kategori sedang sebanyak 17 orang (27\%), sedangkan kategori rendah tidak ada. Hasil uji korelasi Pearson diperoleh $r=-0,083$ dan $p=$ 0,519. Simpulan: Terdapat hubungan negatif antara kepercayaan diri dengan obesitas namun tingkat korelasinya lemah dan tidak signifikan.
\end{abstract}

Kata kunci: obesitas, kepercayaaan diri 
Kepercayaan diri adalah suatu tingkatan rasa sugesti tertentu yang berkembang dalam diri seseorang sehingga merasa yakin dalam berbuat sesuatu, dan menerima diri apa adanya, percaya diri merupakan salah satu modal utama dalam melakukan aktivitas karena kurangnya kepercayaan diri akan berdampak negatif terhadap kehidupan, salah satunya adalah akan menutup diri/mengasingkan diri. ${ }^{1}$

Salah satu faktor yang dapat menurunkan kepercayaan diri seseorang ialah masalah penampilan fisik. Menurut Anthony, faktor kondisi fisik merupakan salah satu penyebab utama rendahnya harga diri dan rasa percaya diri. Seperti yang kita tahu bahwa masa remaja merupakan masa dimana terjadi perubahan fisik yang cukup signifikan. Hurlock menyatakan bahwa masa remaja ditandai dengan perubahan fisik, sikap, serta perilaku yang sangat cepat. Terdapat beberapa macam perubahan yang umumnya dialami oleh remaja yaitu meningginya emosi, terjadinya perubahan fisik, minat, sikap, dan peran yang harus dijalani pada remaja, sehingga para remaja sangat mudah mengalami krisis kepercayaan diri jika menyangkut soal penampilan fisik. ${ }^{2}$ Penampilan fisik yang berubah dan dapat memengaruhi masalah kepercayaan diri pada remaja ialah masalah berat badan. Hal ini dikarenakan anak remaja selalu membandingkan dirinya dengan gambar-gambar yang ada di reklame dan film-film yang banyak menampilkan figur berbadan proposional, sehingga remaja jadi sangat peduli terhadap kondisi fisik atau penampilannya dan akan terus menerus bereksperimen untuk mendapatkan citra diri yang dirasa nyaman bagi mereka, sehingga adanya kecenderungan menjadi gemuk atau mengalami obesitas dapat mengganggu dan menjadi sumber kurangnya rasa percaya diri pada masa remaja.

Berdasarkan uraian latar belakang di atas, maka penulis tertarik untuk menggali dari sudut pandang psikologis yang berkaitan dengan tingkat kepercayaan diri pada remaja yang mengalami obesitas.

\section{METODE PENELITIAN}

Jenis penelitian ini ialah korelasional dengan rancangan potong lintang. Penelitian ini dilaksanakan di SMA Negeri 7 Manado dari bulan Oktober 2015Desember 2015. Populasi ialah siswa yang memenuhi kriteria obesitas. Responden diambil dari kelas 1 sampai kelas 3 yang memenuhi kriteria obesitas. Pengambilan responden pada penelitian ini dengan purposive sampling.

Dalam penelitian ini didapatkan responden sebanyak 62 orang yang terdiri dari 34 siswa dan 28 siswi. Pembuktian hipotesis penelitian dengan korelasi Pearson Product Moment menggunakan program SPSS 20 for windows.

\section{HASIL PENELITIAN}

Penelitian ini dilakukan pada remaja yang mengalami obesitas di SMA Negeri 7 Manado yang berjumlah 62 responden. Berdasarkan jenis kelamin, laki-laki berjumlah 34 orang (54\%) dan perempuan berjumlah 28 orang (45\%). Berdasarkan usia, usia 15 tahun sebanyak 12 orang, usia 16 tahun sebanyak 25 orang, usia 17 tahun berjumlah 23 orang, dan usia 18 tahun sebanyak 2 orang. Berdasarkan tingkat obesitas, obesitas tipe 1 sebanyak 27 orang dan, obesitas tipe 2 sebanyak 35 orang. Berdasarkan tingkat kepercayaan diri, rendah tidak ada, sedang 17 orang dan tinggi 45 orang (Tabel 1).

Berdasarkan tingkat kepercayaan diri dan jenis kelamin, laki-laki yang mempunyai kepercayaan diri tinggi berjumlah 25 orang, sedang 9 orang, dan rendah tidak ada sedangkan untuk perempuan kepercayaaan diri tinggi berjumlah 20 orang, sedang 8 orang, dan rendah tidak ada.

Berdasarkan hasil uji korelasi Pearson Product Moment antara kepercayaan diri dengan obesitas pada siswa SMA Negeri 7 Manado didapatkan nilai signifikansi sebesar 0,519 $(>0,05)$ yang menunjukkan tidak terdapat hubungan bermakna antara kepercayaan diri dengan obesitas (Tabel 2). 
Tabel 1. Karakteristik dasar responden

\begin{tabular}{|c|c|c|c|c|c|c|c|}
\hline \multicolumn{2}{|c|}{ Karakteristik responden } & \multicolumn{2}{|c|}{ Semua responden } & \multicolumn{2}{|c|}{ Obesitas 1} & \multicolumn{2}{|c|}{ Obesitas 2} \\
\hline \multirow{3}{*}{ Jenis kelamin } & & $\mathrm{n}$ & $\%$ & $\mathrm{n}$ & $\%$ & $\mathrm{n}$ & $\%$ \\
\hline & Laki-laki & 34 & 54 & 19 & 56 & 15 & 44 \\
\hline & Perempuan & 28 & 45 & 18 & 64 & 10 & 36 \\
\hline \multirow[t]{4}{*}{ Usia } & 15 & 12 & 19 & 8 & 67 & 4 & 33 \\
\hline & 16 & 25 & 40 & 14 & 56 & 11 & 34 \\
\hline & 17 & 23 & 37 & 14 & 61 & 9 & 39 \\
\hline & 18 & 2 & 4 & 1 & 50 & 1 & 50 \\
\hline
\end{tabular}

Tabel 2. Hubungan Kepercayaan Diri dengan Obesitas

\begin{tabular}{|c|c|c|c|c|c|c|c|c|c|c|c|}
\hline & \multicolumn{4}{|c|}{ Obesitas } & \multicolumn{4}{|c|}{ Jenis Kelamin } & \multirow[t]{2}{*}{$\mathrm{r}$} & \multirow[t]{2}{*}{$\mathrm{P}$} \\
\hline & & I & $\%$ & II & $\%$ & $\mathrm{~L}$ & $\%$ & $\mathrm{P}$ & $\%$ & & \\
\hline \multirow{3}{*}{$\begin{array}{l}\text { Kepercayaan } \\
\text { diri }\end{array}$} & Tinggi & 20 & $44 \%$ & 25 & $56 \%$ & 25 & $56 \%$ & 20 & $\overline{44 \%}$ & \multirow{3}{*}{-0.083} & \multirow[t]{3}{*}{0,519} \\
\hline & Sedang & 7 & $41 \%$ & 10 & $59 \%$ & 9 & $53 \%$ & 8 & $47 \%$ & & \\
\hline & Rendah & - & - & - & - & - & - & - & - & & \\
\hline
\end{tabular}

\section{BAHASAN}

Deskripsi responden berdasarkan jenis kelamin yang disajikan pada Tabel 1 menunjukkan bahwa kelompok terbanyak dari 60 responden ialah laki-laki dengan jumlah 34 orang (54\%), dan perempuan berjumlah 28 (atau 45\%) responden. Hal ini menunjukkan bahwa tingkat remaja yang mengalami obesitas di Manado cukup besar. Hal ini mungkin dikarenakan remaja cenderung menghabiskan waktu di depan komputer dan tempat makan, serta remaja cenderung banyak makan dan jarang olahraga. Pada Tabel 1 mengenai deskripsi berdasarkan usia, responden yang berusia 15 tahun sebanyak 12 orang (19\%), usia 16 tahun 25 orang (40\%), usia 17 tahun 23 orang (37\%), dan untuk usia 18 tahun sebanyak 2 orang (4\%); hal ini menunjukkan bahwa usia remaja rentan terkena obesitas hal ini dikarenakan remaja sering mengonsumsi kalori lebih banyak dari yang diperlukan, ditambah dengan stres yang tinggi atau masalah yang berkaitan dengan emosi cenderung mendorong mereka untuk makan lebih banyak. ${ }^{3}$

Pada Tabel 1 ditampilkan dari 62 responden terdapat 27 orang yang mengalami obesitas tipe 1 (43,5\%) dan 35 orang yang mengalami obesitas tipe 2 (56,5\%); jadi responden terbanyak berada pada obesitas tipe 2. Sturm, seorang ekonom senior dari RAND Corporation dan profesor analisa kebijakan Pardee RAND Graduate School menyatakan kegemukan di jaman modern ini terjadi karena kita dikepung godaan makanan enak yang sangat murah mulai dari fast food sampai makanan ringan. Selain itu hal lain yang tampaknya juga berperan meningkatkan obesitas ialah meningkatnya hiburan elektronik, meningkatnya ketergantungan terhadap angkutan kendaraan, dan perubahan dari pekerjaan fisik ke pekerjaan di balik meja. ${ }^{4}$

Tabel 2 menunjukkan bahwa tidak ada responden yang berada pada tingkat kepercayaan diri rendah. Pada tingkat kepercayaan diri sedang sebanyak 17 orang (27\%) responden dan pada tingkat kepercayaan diri tinggi sebanyak 45 orang (73\%). Jadi responden dengan tingkat kepercayaan diri tinggi lebih banyak daripada responden yang memiliki tingkat kepercayaan diri sedang maupun rendah. Ini menunjukkan bahwa remaja yang memiliki kepercayaan diri tinggi merasa 
bahwa kelebihan berat badan tidak membuat mereka malu atau kurang percaya diri. Hal ini juga didukung dengan hasil penelitian Elvina $^{5}$ yang dilakukan pada siswa SMP Kartika 1-7 Padang yang menunjukkan bahwa sebagian besar siswa yang mengalami obesitas memiliki gambaran diri positif terhadap diri mereka sendiri atau dengan kata lain mempunyai kepercayaan diri yang baik.

Hasil wawancara dengan siswa yang mengalami obesitas menunjukkan bahwa siswa tersebut tetap percaya diri dikarenakan ia dapat berprestasi dalam bidang akademik sehingga siswa tersebut menganggap bahwa kondisi fisiknya bukan penghalang dalam meraih prestasi. Hal ini sejalan dengan yang dikemukakan Bednar, Wells, dan Peterson bahwa prestasi merupakan salah satu faktor untuk dapat memperbaiki tingkat percaya diri remaja. ${ }^{6}$

Menurut Hakim, self confidence (kepercayaan diri) yaitu sebagai suatu keyakinan seseorang terhadap segala aspek kelebihan yang dimilikinya dan keyakinan tersebut membuatnya merasa mampu untuk dapat mencapai berbagai tujuan dalam hidupnya. ${ }^{7}$ Kelebihan berat badan seperti kasus siswa di atas bukan menjadi alasan untuk malu atau kurang percaya diri dikarenakan ia mempunyai kelebihan lain di dalam dirinya yaitu dalam bidang akademik. Tabel 2 menunjukkan bahwa siswa laki-laki dan perempuan lebih banyak mempunyai kepercayaan diri tinggi, sehingga dapat disimpulkan bahwa obesitas kurang berpengaruh terhadap kepercayaan diri remaja laki-laki maupun perempuan karena kedua kelompok ini secara umum sama-sama berada pada kepercayaan diri yang tinggi. Hasil penelitian ini berbeda dengan hasil penelitian Conger dan Peterson dimana pada masa remaja, baik remaja laki-laki maupun perempuan sangat sibuk dengan penampilan fisik bahkan mengubah penampilan fisik sebaik mungkin karena penampilan tidak menarik akan menimbulkan ketidakpuasan yang pada akhirnya membuat remaja baik lakilaki maupun perempuan menjadi tidak percaya diri, begitu juga sebaliknya. ${ }^{8}$ Hasil penelitian ini juga berbeda dengan pendapat Al-Mighwar ${ }^{9}$ yang mengatakan bahwa perubahan fisik memengaruhi sikap dan tingkah laku remaja baik laki-laki maupun perempuan karena mengakibatkan remaja kurang percaya diri.

Berdasarkan hasil uji korelasi Pearson Product Moment antara kepercayaan diri dengan obesitas pada siswa SMA Negeri 7 Manado didapatkan nilai kemaknaan sebesar 0,519(>0,05) yang menunjukkan tidak terdapat hubungan bermakna antara kepercayaan diri dengan obesitas. Hal ini disebabkan karena kondisi fisik bukan satusatunya faktor yang dapat menentukan tingkat kepercayaan diri seseorang. Tingkat kepercayaan diri seseorang ditentukan oleh berbagai faktor, baik faktor internal yang meliputi kondisi fisik konsep diri, harga diri, dan pengalaman hidup maupun faktor eksternal seperti pendidikan, pekerjaan, dan lingkungan.

Selain itu dari hasil pengamatan dan wawancara terhadap siswa lain yang mengalami obesitas menunjukkan bahwa, siswa tersebut dapat diterima dengan baik di lingkungan sekitar rumah maupun di sekolah, sehingga rasa percaya diri dapat tumbuh dengan sendirinya. Menurut Santrock seseorang yang mendapatkan dukungan sosial dari teman sebaya secara positif maka akan lebih percaya diri dalam melakukan sesuatu, ${ }^{10}$ sehingga penerimaan sosial yang baik juga dapat berpengaruh dalam menentukan kepercayaan diri seseorang. Hal ini juga di dukung dengan penelitian sebelumnya yang dilakukan Renman et al. ${ }^{11}$ dengan jumlah sampel 116 remaja (58 obesitas dan 58 kontrol) yang terdiri dari 60 laki-laki dan 56 perempuan. Penelitian ini dilakukan dengan menggunakan alat ukur "I think I am,Youth Self Report and a lifestyle questionnaire". Hasil penelitian Renman menunjukkan bahwa tidak terdapat hubungan antara kepercayaan diri dengan obesitas.

\section{SIMPULAN}

Dari hasil penelitian siswa obes di SMA Negeri 7 Manado dapat disimpulkan bahwa sebagian besar memiliki tingkat 
kepercayaan diri tinggi. Tidak terdapat hubungan bermakna antara obesitas dengan kepercayaan diri.

\section{SARAN}

1. Bagi siswa obes di SMA Negeri 7 Manado diharapkan dapat mempertahankan kepercayaan diri dengan yakin akan kemampuan diri sendiri dan juga selalu berpikir positif baik terhadap diri sendiri maupun orang lain. Selain itu juga diharapkan agar dapat menjaga pola makan, teratur berolahraga, dan terus membangun interaksi sosial yang baik antara satu dengan lainnya.

2. Bagi Sekolah diharapkan untuk tetap mengaktifkan bahkan memperbanyak kegiatan ektrakurikuler, kegiatan kerohanian, dan terus menunjang para siswa untuk berprestasi dalam berbagai bidang akademik sesuai minat dan bakat.

3. Bagi peneliti lanjut disarankan untuk mempertimbangkan variabel-variabel lain yang berhubungan dengan kepercayaan diri pada remaja, seperti konsep diri, pengalaman hidup, pendidikan, ekonomi, pola asuh orang tua, teman sebaya dan sekolah serta meneliti pada subjek yang lain, seperti siswa-siswi Sekolah Menengah Pertama, mahasiswa, dan yang sudah bekerja.

\section{UCAPAN TERIMA KASIH}

Ucapan terima kasih ditujukan pada dr. Joice Kandou, SKJ, Cicilia Pali, SPsi, MPSi, dan kepada semua pihak yang baik secara langsung maupun tidak langsung telah menumbuhkan ide pada penulis.

\section{DAFTAR PUSTAKA}

1. Sigmund F. Pengertian kepercayaan diri. [cited 20 Oktober 2015]. Available from: http://www.anneahira.com/pengertian -kepercayaan-diri.html

2. Choirunisa K. Hubungan antara Body Image dengan Kepercayaan Diri pada Remaja Putri [ Skripsi]. Surakarta: Universitas Muhammadiyah; 2011.

3. Obesitas pada remaja. [cited 29 Februari 2016]. Available from: https://www. tanyadok.com/anak/obesitas-padaremaja

4. Obesity [cited 29 februari 2016]. Available from: http://www.rand.org/about/ people/s/sturm_roland.html

5. Elvina. Hubungan obesitas dengan konsep diri remaja SMP Kartika Padang [penelitian]. Padang: Fakultas Keperawatan Universitas Andalas; 2009.

6. Hubungan kepercayaan diri dengan pemngambilan keputusan. [cited 22 Februari 2016]. Available from: http://library.binus.ac.id/eColls/eThes isdoc/Bab2/2012-1-00568ps\%20bab\%202.pdf

7. Pengertian self confidence [cited 18 Februari 2016]. Available from http://www.psychologymania.com/20 12/06/pengertian-selfconfidence.html

8. Indika K. Gambaran Citra Tubuh Remaja Yang obesitas [skripsi]. [Medan]: Fakultas Psikologi Universitas Sumatera Utara; 2010.

9. Al-Mighwar M. Psikologi Remaja (Petunjuk Bagi Guru dan Orangtua). Bandung: Pustaka Setia, 2006.

10. Universitas Sumatera Utara. Obesitas; 2008 [cited 28 Oktober 2015]. Available from:

http://repository.usu.ac.id/bitstream/1 23456789/31665/4/Chapter20II.pdf

11. Renman C, Engstrom I, Silfvedral SA. Mental health and physicosocial characteristics in adolescent obesity: a population-based case-control study. Acta Paediatr. 1999;88:998-1003. 